\title{
Skill distribution and regional unemployment disparities in Hungary
}

Distribuição de qualificações profissionais e disparidade regional de desemprego na Hungria

Répartition des qualifications professionnelles et disparité régionale du chômage en Hongrie

Distribución de cualificaciones profesionales y disparidad regional de desempleo en la Hungría

\section{László Czaller and Hajnalka Lőcsei}

\section{(2) OpenEdition}

Journals

Electronic version

URL: http://journals.openedition.org/espacoeconomia/4912

DOI: 10.4000/espacoeconomia.4912

ISSN: 2317-7837

Publisher

Núcleo de Pesquisa Espaço \& Economia

\section{Electronic reference}

László Czaller and Hajnalka Lőcsei, «Skill distribution and regional unemployment disparities in Hungary », Espaço e Economia [Online], 13 | 2018, Online since 16 December 2018, connection on 19 April 2019. URL : http://journals.openedition.org/espacoeconomia/4912 ; DOI : 10.4000/ espacoeconomia.4912

This text was automatically generated on 19 April 2019.

(C) NUPEE 


\section{Skill distribution and regional unemployment disparities in Hungary}

Distribuição de qualificações profissionais e disparidade regional de desemprego na Hungria

Répartition des qualifications professionnelles et disparité régionale du chômage en Hongrie

Distribución de cualificaciones profesionales y disparidad regional de desempleo en la Hungría

László Czaller and Hajnalka Lőcsei

\section{Introduction}

Although labor markets are usually analyzed on the national level (Blanchard, 2006), in the past two decades within-country disparities of unemployment have attracted considerable attention among academics and policymakers worldwide (Overman \& Puga, 2002; OECD, 2005). Primary reasons of this growing interest were the persistency and significance of regional unemployment disparities which were believed to have adverse effects on aggregate economic performance. According to Taylor (1996), the reduction of regional unemployment disparities lowers inflationary pressure, allows cutting back spending on unemployment subsidies and also eases social tensions.

Nevertheless, the persistence of spatial inequalities of unemployment has not been fully explained yet (Elhorst, 2003). Within the neo-classical strand of the literature, the widely accepted explanation of regional unemployment disparities is the failure of the adjustment processes to absorb local asymmetric shocks. Without any institutional barriers and supply side rigidities, migration of the unemployed and capital flows would completely remove unemployment disparities or at least set them back to their equilibrium level (Blanchard \& Katz, 1992; Marston, 1985). As argued by Bornhorst and 
Commander (2004), however, the existence of equilibrium is an unrealistic assumption in dynamic transitional systems undergoing continuous structural change. Moreover, observed factor flows often contradict or fall short of the flows predicted by neoclassical theory. Based on the lack of empirical evidence, therefore, the possibility that factor mobility can equilibrate unemployment across regions is rejected by most of the scholars. Empirical evidence on the direction of migration is rather in line with the new economic geography (NEG) and endogenous growth theory literatures which assert that at the presence of agglomeration benefits, market distortions, or skill-biased technological change spatial concentration of labor may lead to self-enforcing divergence of regional production (Fujita, Krugman \& Venables, 1999), and rising inequalities of unemployment ( Epifani \& Garcia, 2005). Although elements of NEG might be eligible to explain persistent disparities of unemployment in a fully developed market economy marked by a preexisting spatial structure, it still cannot answer the question of how regional unemployment disparities evolve in the first place.

The first attempt to model the speed of transition and explain the emergence of unemployment and labor reallocation has been made by Aghion and Blanchard (1994). According to their model, economic transition is represented as the process of labor reallocation from the declining state sector to the emerging high-productivity private sector, where the mismatch between private sector vacancies and the number of jobseekers translates into unemployment, which in turn determines the speed of transition through its downward effect on wages and fiscal pressures. This model indeed explain some patterns of the adjustment process at the national level, but without a framework on supply side constraints and institutions, they have some troubles in explaining regional unemployment disparities. To extend these models, the role of asymmetric spatial impacts of rigid wages, union power, unemployment benefits and early retirement schemes have been broadly examined (Boeri, 2000; Boeri \& Terrell, 2002), but lesser attention has been paid to the initial skill composition of the regional labor supply and directed technological change, which might also play a crucial role in determining the success of economic restructuring and permanent spatial patterns of unemployment as it is frequently argued by economic geographers and the proponents of endogenous growth theories (Ferragina \& Pastore, 2008). Recently, Jurajda and Terrell (2009) made a remarkable attempt to examine the role of skill endowments on regional unemployment disparities by taking the theoretical arguments on the spatial consequences of skill distribution to a transitional context, and gather empirical evidence from four transitional countries (Bulgaria, Czech Republic, Hungary, Ukraine). Their exploratory analysis confirmed the hypothesis that the spatial distribution of human capital has an important role in explaining regional unemployment disparities. By estimating an intertemporal econometric model, Ábrahám and Kertesi (1998) obtained similar results in Hungary, while Newell (2005) found that human capital accounts for about the half of the regional variation of unemployment in Poland. These results, while suggest a strong negative relationship between human capital endowments and unemployment, hardly say anything about the causal effects of human capital. Coefficients on human capital variables are subject of endogeneity concerns due to possibly omitted variables or reverse causality.

The aim of this paper is, then, to continue the research on the emergence and persistence of regional labor market inequalities by identifying the effects of skill endowments on regional unemployment rates in Hungary. To this end, we first lay down the theoretical 
underpinnings of the empirical analysis by providing a brief review on the related literature, then, we draw some stylized facts about the spatial evolution of unemployment devoting attention to the long-term historical perspectives without which the uneven spatial patterns of human capital and persistent labor market inequalities cannot be construed. Then, we analyze the effects of human capital on regional unemployment using LAU-1 data for 2001 and 2011. To address the problem of endogeneity, we use historical data on literacy from 1880 as an instrument for our human capital variable, namely the share of college educated population. Finally, to test whether the imperfect substitution between different skills contributes to the overall effects of regional skill endowments, we repeat the regression analysis for skill-specific unemployment rates.

Our results suggest that the lack of convergence in regional unemployment rates can be originated in the uneven spatial distribution of human capital. Regions with higher shares of skilled individuals, on average, tend to have lower unemployment rates because, on the one hand, among high-skilled individuals the unemployment rate is generally lower, while on the other hand, workers with different skills are complements in production.

\section{Skill distribution and unemployment: some theoretical considerations}

As it is shown by several empirical studies there exists a strong negative correlation between the relative share of skilled labor and unemployment rate (Burridge \& Gordon, 1981; Malizia \& Ke, 1993; Partridge \& Rickman, 1997; Lopez-Bazo et al, 2002). The theoretical literature offers two set of explanations for this unambiguous result. The first refers to the initially lower risk of unemployment at higher educational levels (Elhorst, 2003), while the second one emphasizes the importance factor complementarities, and directed technological change (Jurajda \& Terrell, 2009). According to the first set of explanations the demand is usually higher for skills and knowledge possessed by workers with higher educational or expertise levels, which provides them a more stable and relatively advantageous labor market position, making them less prone to mass layoffs. skilled workers have even better employment chances particularly in labor markets where employers deem educational attainment as a signal of productivity or lower training costs. In the absence of prior information about the intrinsic abilities of potential workers, employers are obliged to recline upon the observable measures of human capital and prefer the applicant with more education. ${ }^{1}$

Moreover, since skilled workers are more provident, have more information about labor market prospects and possess better abilities to recognize new employment opportunities. Skilled people search for suitable jobs that meet their qualifications much more effectively, and they are also disposed to take low-skilled jobs temporarily until better employment can be found. Consequently, more educated workers switch jobs more easily and face lower risk of long-term unemployment. Therefore, in regions where the share of high-skilled workers is relatively higher the unemployment rate is expectedly lower.

Although some elements of this set of explanations have great relevance, some of them are highly problematic. They do not reveal the economic processes that lead to the 
increasing demand for the knowledge of skilled workers and they also rely on the questionable assumption that workers with different amount of schooling are close substitutes. Therefore the second explanation which builds on skill complementarity, the idea of directed technological change, and skill-selective migration patterns seems more promising in explaining the persistence of regional unemployment rate differences. It provides a broader and more dynamic conceptual framework, which is also eligible to explain relatively higher demand for skilled workers.

It seems evident that skilled people are not evenly distributed across regions. The spatial distribution of human capital is constantly reshaped by means of local knowledge creation, processes of socialization, mortality and of course labor migration. Highly skilled individuals, who previously invested more time, money and effort to acquire skills and gain experience than their unskilled peers, move into regions where the returns to their knowledge and qualification are the highest. Standard neoclassical models predict that high-skilled workers migrate to poor regions where the expected skill premium is higher due to the relatively higher local demand for skills. Recent empirical evidence however disapproves the validity of this prediction by showing that the skill premium is higher in densely populated regions where the skill supply is larger (Glaser \& Saiz, 2004; Glaeser \& Resseger 2010). The literature provides two distinct explanations for this controversy. Economic geographers often argue that highly skilled workers are more productive when they are in a "creative milieu" surrounded by their peers. Such creative environments generate external returns to human capital by providing better opportunities for skill acquisition, and by facilitating knowledge exchange through personal interactions (Glaeser, 1999; Glaeser, 2005; Storper \& Venables 2004). Such external benefits increase the productivity and wages of local workers and facilitate regional growth (Lucas, 1988; Azariadis \& Drazen, 1990; Rauch, 1993). ${ }^{2}$

Nonetheless, external returns to human capital are not the only source of higher returns to skills in skill-abundant regions. If modern production technologies complement skilled labor, any improvements in the applied technology increase the local demand for skilled workers, which in turn leads to higher returns to human capital even in the absence of externalities. ${ }^{3}$ By the same token, though, the spatial distribution of human capital also determines which regions will lead in terms of knowledge creation and technology adoption. Since firms can only undertake R\&D activities and make good use of intermediate knowledge if there is a sufficient amount of supply of skilled labor available. Thus, endogenous technological improvements are expected in human capital rich regions (Acemoglu, 2003).

Endogenous technological change and externalities launch irreversible, self-reinforcing concentration of skills and stimulates employment growth in prosperous urban centers. However, not only highly skilled workers, but also lower workers benefit from these processes. If different skill levels are bad substitutes in the production process, an upward shift in the demand of skilled labor also increases the demand for unskilled workers (Katz \& Murphy, 1992; Autor, Katz \& Krueger, 1998). Nevertheless, labor market opportunities of workers with less education remain relatively advantageous in human capital rich regions, even if local firms outsource routine occupations into peripheral regions. Population growth in prosperous regions also expands the relatively more laborintensive non-traded sector (e.g. local services), increasing the employment share of lowskilled workers (Goos; Manning \& Salomon, 2014; Manning, 2004). ${ }^{4}$ It is especially important if the presence of skilled individuals require additional intermediate cultural 
services to spend their leisure time (Shapiro, 2006). Consequently, if geographical concentration of human capital raises productivity through external effects or the technological change is skill-biased, the complementarity between labor with different skill endowments facilitate employment growth and lowers the risk of unemployment in each skill type. Considering that skill-biased technological change is endogenous, spatial differences of average schooling has a permanent effect on the regional variation of unemployment rates. Because of their brighter labor market prospects regions with high levels of human capital attract all workers, irrespectively of their skill endowments. However, higher average wages and better labor market opportunities are offset by negative attributes, like higher costs of living and property values which displace lowincome residents from prosperous regions, or browbeat them into high-distance commuting. Increasing costs of living in regions with higher levels of human capital also contributes to the development of poverty traps in less advantageous regions. The mobile part of the workforce leaves these regions but those who stay, get into an even more difficult situation, because in the absence of skilled labor, technology and physical capital avoid these regions. Due to the self-reinforcing nature of this process the initial human capital endowments and unconstrained mobility, in the long run, raise regional disparities of unemployment and widen the gap between rich and poor regions.

\section{The emergence of regional unemployment disparities in Hungary: The role of inherited skill endowments}

Focusing on post-socialist transitional economies helps us understanding how regional unemployment rate differentials emerge at the first place during the initial phase of economic transition, and how they stabilize as the restructuring international trade, the inward flow of FDI and the adaptation of new applied technologies reshape the skill composition of labor demand. ${ }^{5}$ In this section we draw some stylized facts about the procession of the Hungarian transition, and the role of long-run structural heritages in the emergence of regional unemployment disparities. These facts might help disclose the role of spatial disparities of human capital. (Short description of regional unemployment disparities see textbox!)

\section{Unemployment before the regime change}

Although ideological considerations of the socialist system tried to conceal unemployment (as we know it today), the seeds of the problem started to appear already in the second half of the eighties. During this period it became apparent that the state has to find a legal and financial solution to the problem of those citizens who had previously lost their jobs for reasons which may not be ascribed to them, but to their employers. The first instruments set out to remedy the problem were purported to sustain ongoing employment and to temporarily pay social welfare benefits to those who did not have a job and were looking for work. These can be considered as the first instruments of the Hungarian employment policy, whose introduction undermined the rationality of the ideologically declared aim of full employment. Since the unemployed were not officially registered during the socialist era, only a few approximations on the number of unemployed are available. ${ }^{6}$ According to Ferge (1988), the unemployment rate was about 1-3 percent in the middle of the eighties, however this approximation does not include 
the mass of those who had jobs, but whose employment was unnecessary and undue. From the beginning of the seventies larger firm size and more employment meant proportionally more operational aid and also more beneficial taxation conditions which incited employers to hire more workers than reasonable (Kornai, 1992). Although this practice was in line with the Marxist ideological premises of right-to-work and full employment, it worsened productivity and caused the phenomenon commonly referred to as "unemployment behind the gates" which concerned about 15-20 percent of the workforce in Hungary at the end of the eighties (Meusburger 2001).

\section{Short description of regional unemployment disparities in Hungary}

The regional pattern of unemployment in Hungary has been relatively stable since the second half of the 1990's, clearly reflecting also the spatial structure of socio-economic development. Simply saying, the country can be divided into two parts: one having rather favorable position, competitiveness and ability to comply with the altered circumstances, with high employment level, and another having much less favorable situation, hardly attracting FDI and continuously lagging behind.

GDP per capita in Hungarian regions, 2011

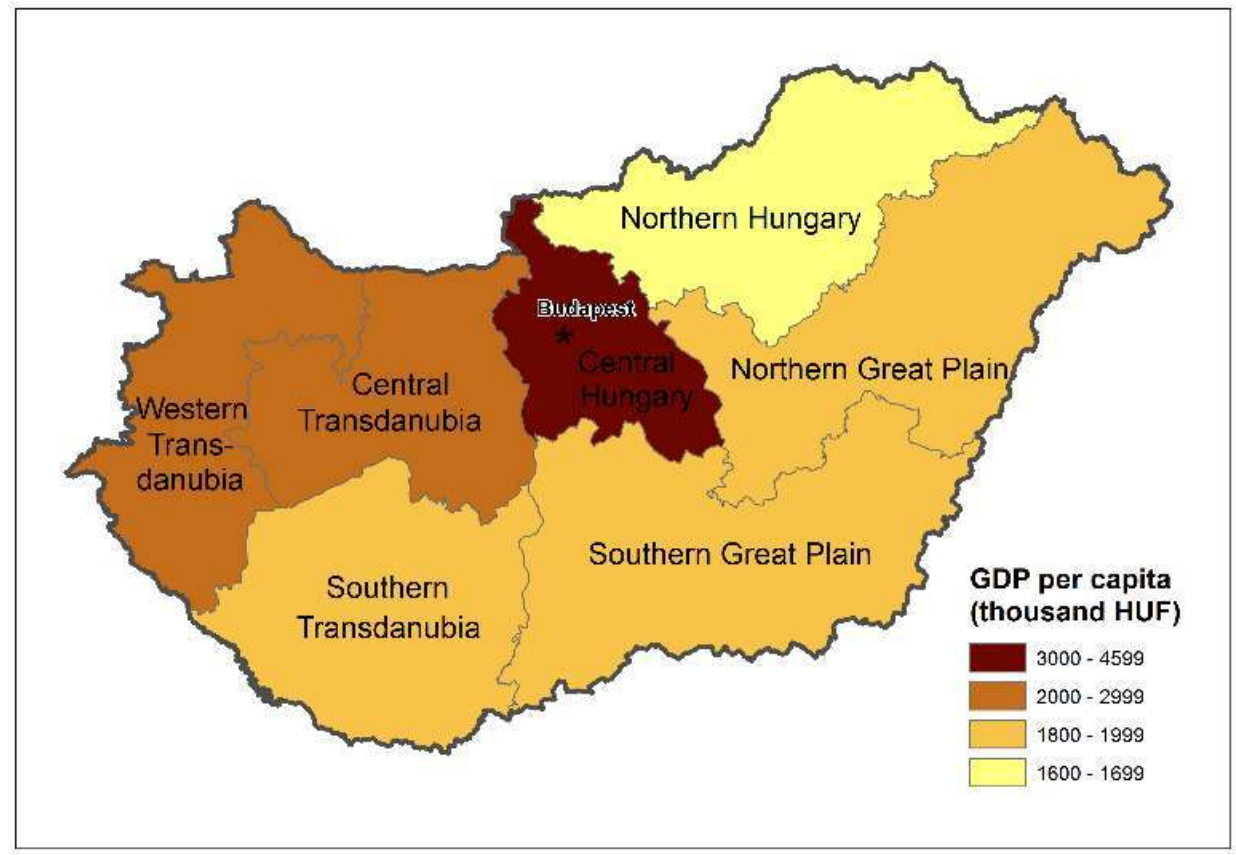

SOURCE OF DATA: HCSO 


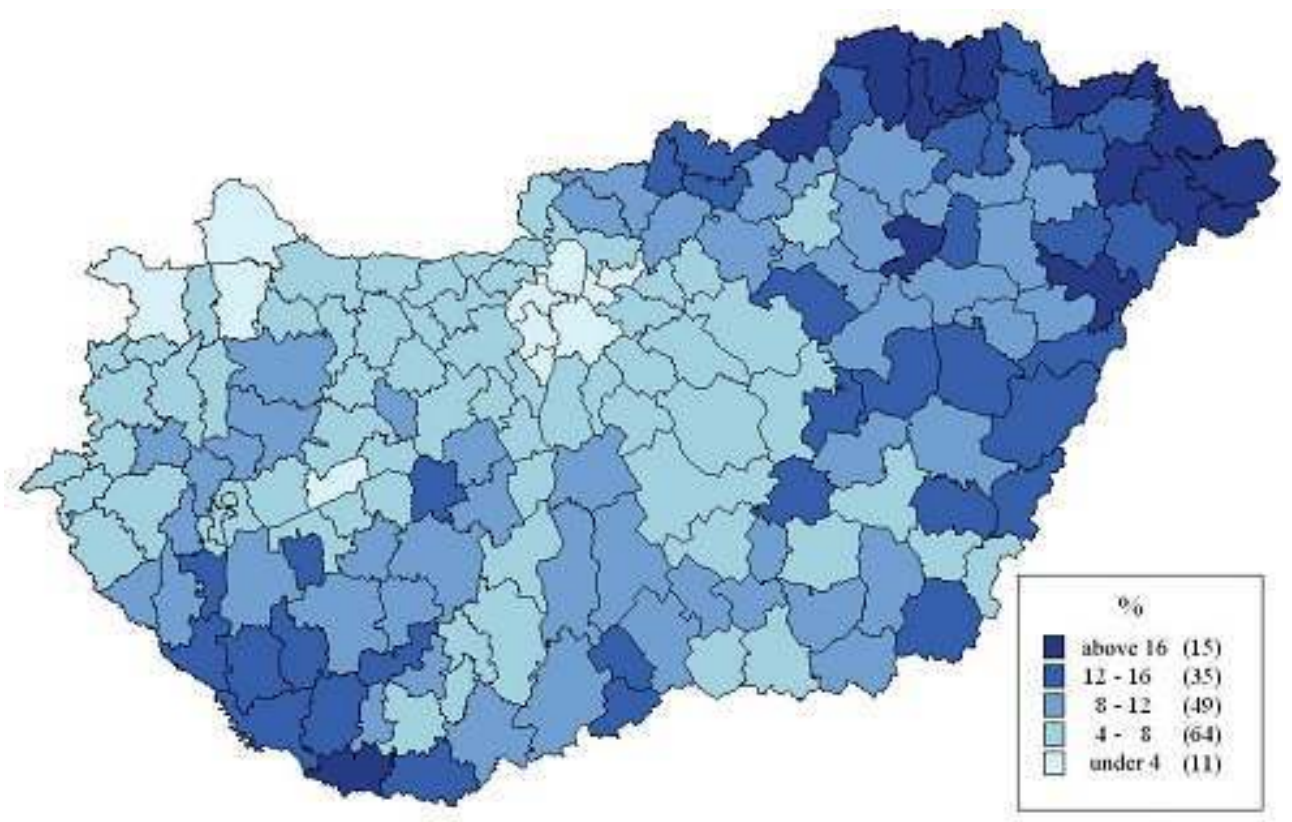

SOURCE OF DATA: NATIONAL EMPLOYMENT SERVICE

Where are the developed regions with the lowest unemployment rate?

- The urban agglomeration of Budapest concentrates approx. one quarter of the Hungarian population and produces about the half of total GDP. Also foreign investments in the tertiary sector were mainly registered in this area.

- The industry-lead growth has formed a stable development zone in the Northwestern part of Hungary (in the regions of Central and Western Transdanubia), which was characterized by the lack of workforce in the years before the global recession. Large companies and their suppliers in the export-oriented manufacturing industry were established in the last 10-15 years there. Also the geographical position of this region has an influence on attractiveness: the easy accessibility of the Western border and the M1 motorway leading to the Western European markets evidently mean advantage.

- There are relatively low unemployment rates in microregions with tourism-oriented profiles around Lake Balaton, located in the middle of Transdanubia.

Where are the underdeveloped peripheral regions with critical employment levels?

- Unemployment was the largest problem in the Eastern third of the country. Particularly critical was (and remained) the state of the microregions along the North-Eastern border.

- Peripheral microregions in Southern-Transdanubia are counted here as well.

- Employment problems are also present in "inner peripheries" characterized by microregions with no major cities and hard accessibility.

In the latter areas it was not simply the high rate of jobseekers that caused problems, but also the unfavourable structure of employment (high rate of low-skilled and long-term unemployed people). In areas burdened by social and often ethnic tensions (with Romani population) and with low entrepreneurial activity, labor demand is very low due to the absence of large enterprises. Additionally, these areas are far from major cities that could possibly offer job opportunities. 
It can be stated that at the turn of the millennium certain convergence clubs had arisen among regions: the difference between the developed regions (Western-Transdanubia, Central-Transdanubia, Central-Hungary) and other regions of Hungary had increased. The economic duality, which can be derived from the location and agglomeration economies, and the significant spatial segregation of favorable and unfavorable regions, is well represented by the strong positive spatial autocorrelation level of the rate of jobseekers (Moran's I was 0.73 in 2008).

\section{Regional unemployment dynamics during transition}

Structural problems arising from the system-specific regulations of the socialist labor market revealed themselves most conspicuously after the regime change in 1990. Many state-owned enterprises, especially the less productive and competitive ones collapsed under the pressures of the new market economy environment. The situation was exacerbated even further by the disintegration of COMECON (Council for Mutual Economic Assistance) in 1991, which curtailed the agricultural sector from its stabile markets. These processes led to mass layoffs of which the first victims were day-laborers and those unskilled workers who had been unnecessarily employed during the previous decade.

Figure . Unemployment in Hungary, 1990-2011

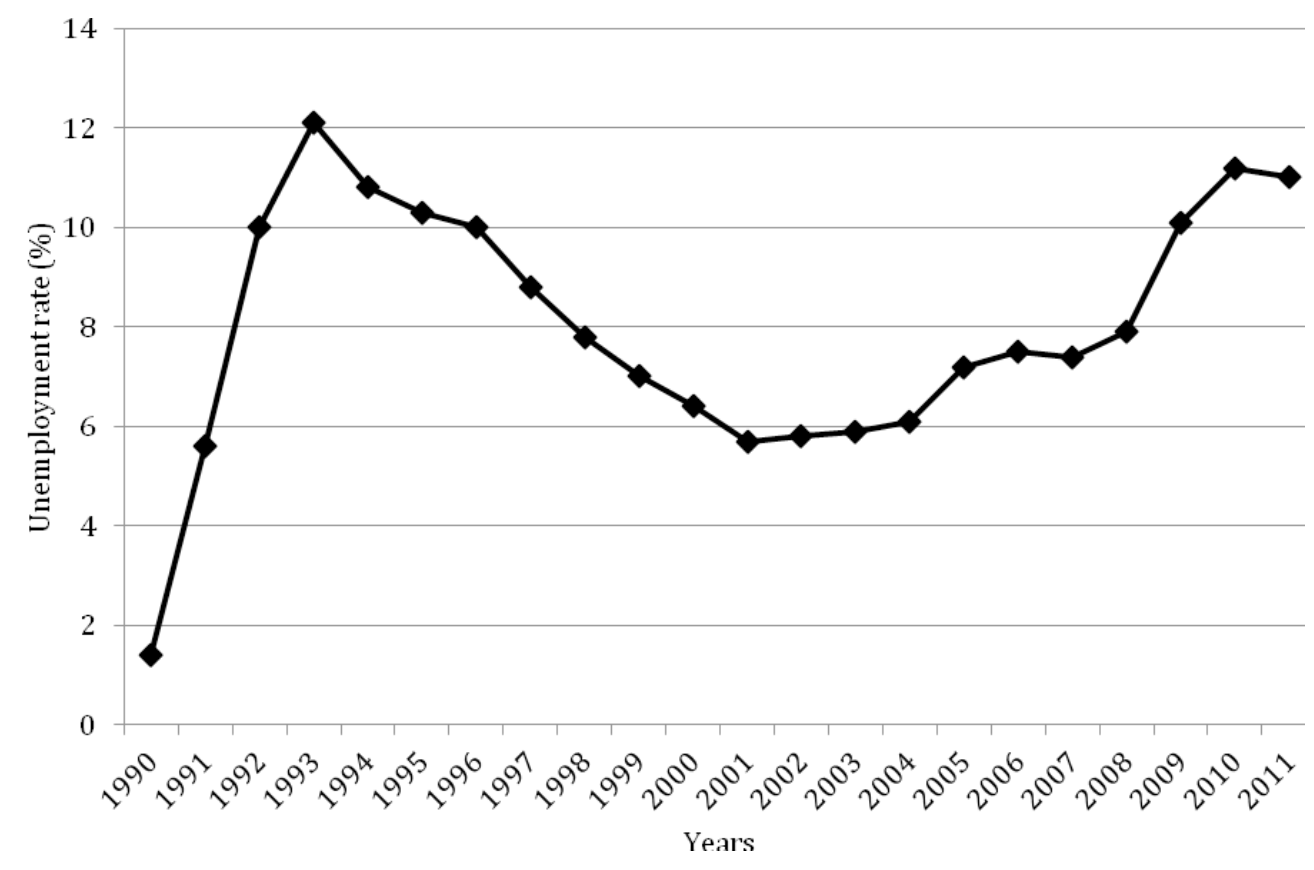

Notes: Unemployment rate refers to the percentage share of the unemployed in the labor force aged 15-64. Source: HCSO Labor Force Survey

As it is shown by Figure 1, due to the mass layoffs, the number of registered unemployed reached 100000 and the unemployment rate rose to 1.9 percent in 1990. In 1991 the unemployment rate quadrupled, and then in the following two years it doubled again reaching the peak of 12.1 percent in 1993. It took six years for unemployment to drop to its half, reaching its two-decade minimum of 5.7 in 2001. Employment growth occurring in the second period of transition however did not affect all educational groups equally. 
Price liberalization and the restructuring of international trade have changed the structure of demand for products and services, shifting production largely toward skillintensive industries as a result (Commander \& Köllö 2008). The inter-sectorial reallocation of employment was mostly triggered by the inward flow of FDI which indeed played a significant role in the emergence and development of high-tech industries, and the technological improvement of the Hungarian economy (Kézdi, 2002). Structural reallocation and skill-biased technological change together reduced the employment opportunities of less-skilled workers, who still remained overrepresented among the unemployed population. A proof of this can be seen in Figure 2 which depicts the educational distribution of unemployment between 1992 and 2011. ${ }^{7}$ During the early stages of economic transition about three-fourths of the unemployed belonged to the two lowest educational categories (primary education or less; lower secondary education). As the enrollment rates in the upper secondary education started to increase during the nineties and the expansion of tertiary education made the supply of college-educated workers more elastic, the share of more educated workers out of the total unemployment shares increased, but the share of less-skilled workers remained disproportionally high. In 2011 more than 60 percent of the unemployed population had less than upper secondary education.

Figure . Distribution of unemployment by educational level

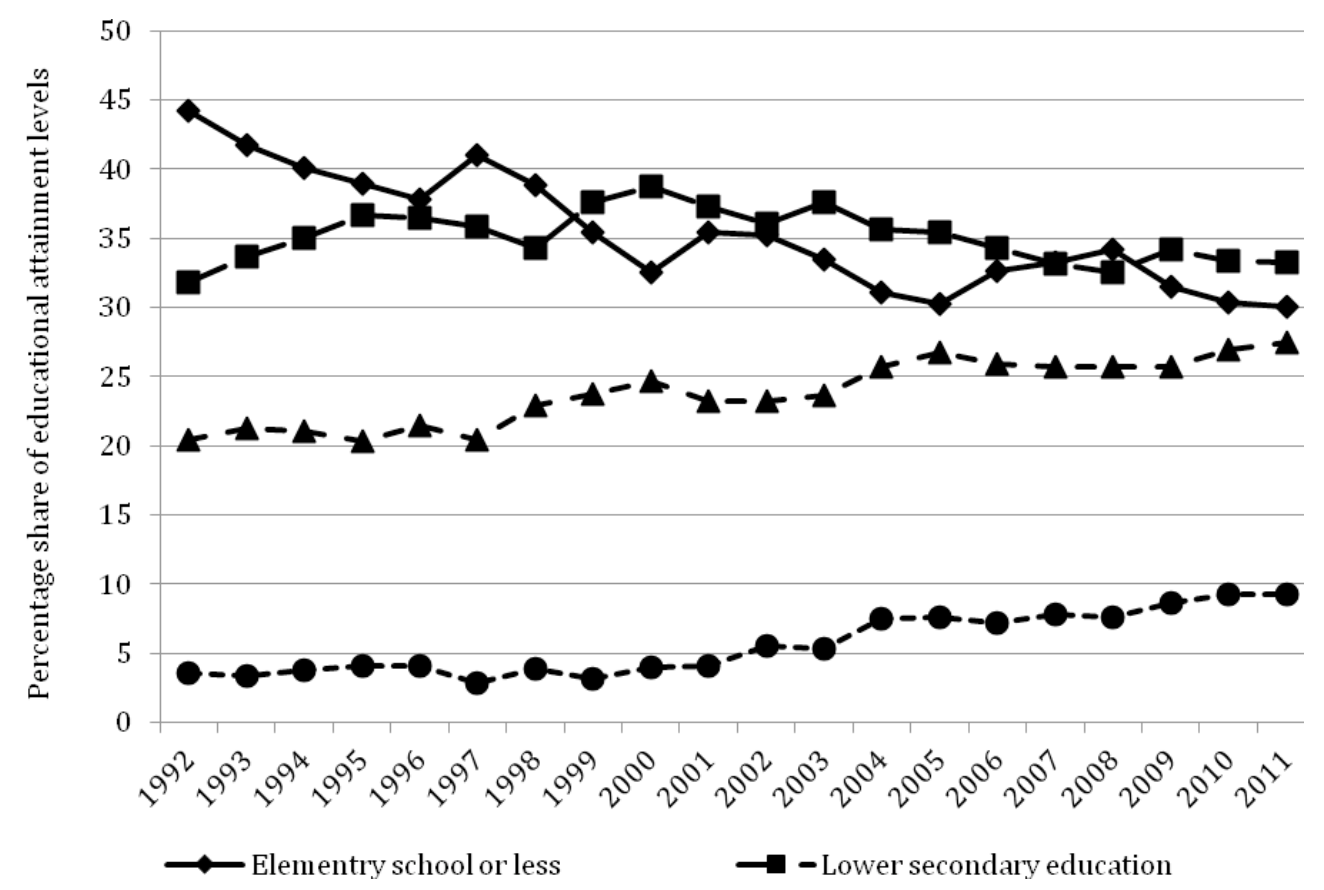

SOURCE: HCSO LABOR FORCE SURVEY

Educational attainment can be perceived as a stabile structural constituent of unemployment which is also reflected in the regional variations of unemployment rate. Figure 3 reports the unemployment rate in 1993 against the percentage share of collegeeducated population over 25 years of age out of the total population over 25 years of age in 1990 for the cross-section of 175 Hungarian LAU-1 sub-regions. Both variables are expressed in percentage of the mean. The estimated slope coefficient is -0.762 with the standard error of 0.092 . The coefficient is significant which suggests that the stock of 
college-educated individuals had noticeable impact on the regional unemployment in latter stages of the Hungarian transition.

Figure . Share of college educated population and unemployment rate across Hungarian LAU-1 sub-regions during the early stages of transition

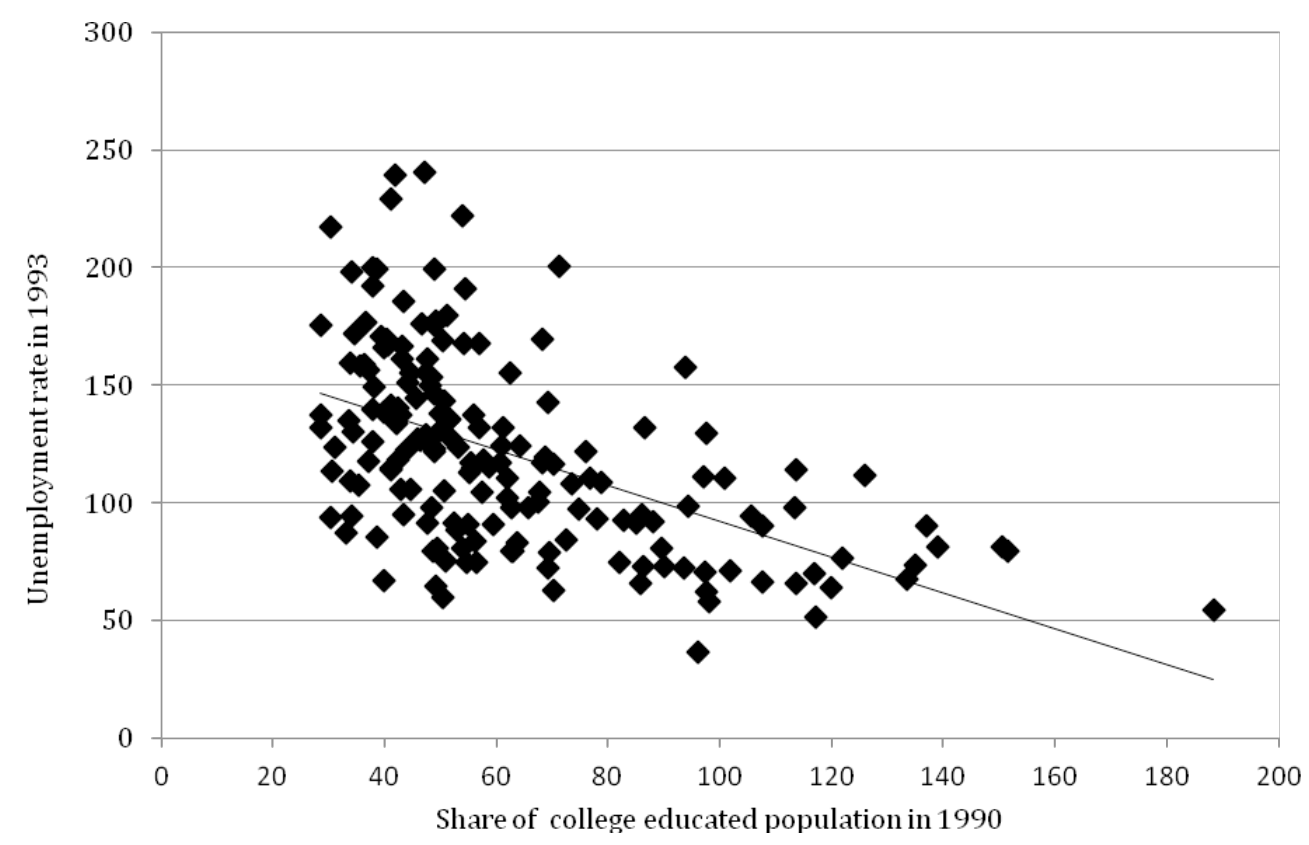

Notes: Both variables are expressed in the percentage of the national mean. Units of observation are LAU-1 sub-regions. Data on the share of college educated population is from 1990 Census, data on unemployment stems from the database of National Employment Service. The line shows the fitted OLS regression line. The slope coefficient is -0.762 with the standard error of $0.092 . \mathrm{R}^{2}=0.321$.

Ábrahám and Kertesi (1996) drew similar conclusion from their inter-temporal analysis of regional unemployment and its determinants. They found that during the entire transitional period the regional variations of two factors namely the share of Romani population - the largest ethnic minority in Hungary - and human capital endowments measured as the average years of schooling had the largest impact on the regional unemployment differentials. With the progression of the transitional process, however, only human capital was proved to be a permanently important explanatory factor, the share of Romani population reduced in significance. The reason is probably that regions with higher levels of human capital attracted FDI during the second period of transition. Questionnaire-based surveys inquiring the motivations behind the location decisions of foreign firms confirmed the importance of the educational level of the regional workforce. Moreover, quantitative studies showed that the inflow of FDI tend to follow the spatial patterns of human capital (Fazekas, 2005; Jurajda \& Terrell, 2009). This is especially true for high-tech industries where applied technologies require an increasingly larger spectrum of skills and up-to-date knowledge.

Spatial skill distributions in the early periods of economic transition had permanent effects on the concentration of economic activity and the increasing regional differences of unemployment probabilities through the inflow of FDI and technological adaptation. Figure 4 reports the after crisis unemployment in 2011 rate against the share of college graduates in 1990 for the same cross-section of sub-regions. The coefficient and the 
corresponding standard error are substantially analogous to those depicted in Figure 3 ( $-0.788,0.083)$. Although these scatter plots indeed do not establish any causal relationships, they allude to the long-term effects of inherited skill distributions and the stability of spatial unemployment differentials.

Figure. Share of college educated population in 1990 and unemployment rate in 2011

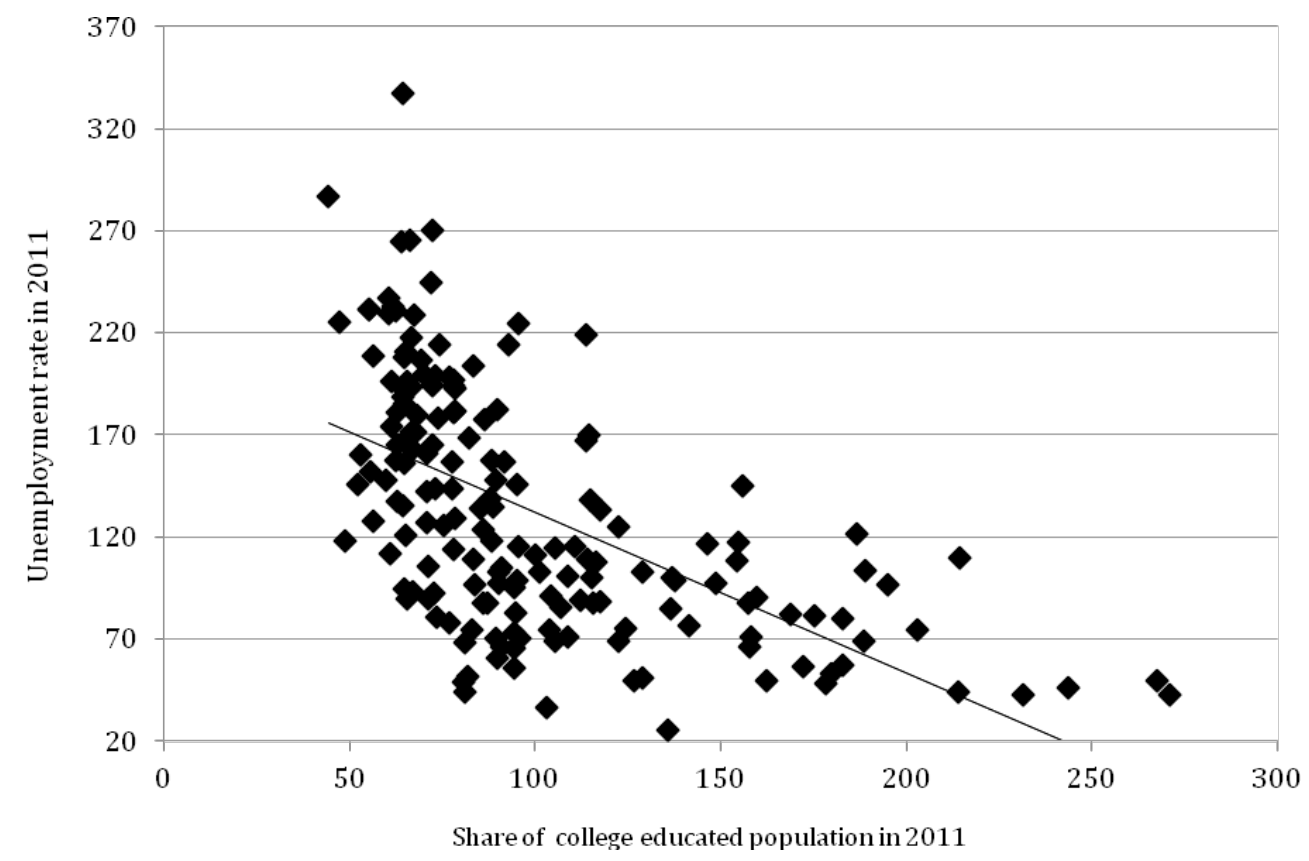

Notes: Both variables are expressed in the percentage of the national mean. Units of observation are LAU-1 sub-regions. Data on the share of college educated population is from 2011 Census, data on unemployment stems from the database of National Employment Service. The line shows the fitted OLS regression line. The slope coefficient is -1.008 with the standard error of $0.083 . R^{2}=0.231$

\section{Empirical evidence on the effects of regional skill endowments}

\section{Estimation issues}

Studies over the last two decades provide indirect evidence on the role of human capital in shaping the regional distribution of unemployment, however the causal effects of human capital are yet unknown. The aim of this section is to identify these effects. However this task is not entirely problem-free. One of the most important problems occurring in such econometric analyses is the spatial sorting of skills (Glaeser \& Resseger, 2010). The spatial distribution of human capital is not random, which makes it difficult to dissociate the causal effects of human capital from other factors that simultaneously attract (push) skilled workers and decrease (increase) unemployment. As it is shown by several studies the share of skilled labor is higher in densely populated urbanized regions, where the unemployment is also shown to be lower (Glaeser \& Saiz 2004; Bacolod, Blum \& Strange 2009). Other sources of external returns to scale such as specialized servicing activities, the possibilities for cooperative research and development activity, and the advantage of industry-wide marketing attract skilled labor 
to urbanized regions and also increase employment (Shapiro, 2006). On the other hand, remoteness, higher commuting costs, the lack of investments and opportunities for learning and knowledge exchange in sparsely populated rural regions increase the risk of unemployment and spur skilled labor to leave and get employed elsewhere (Pissarides \& Wadsworth, 1989; Köllö, 2006).

To deal with the issue of omitted variables and provide consistent estimates for the effects of human capital endowments on unemployment, we first make an attempt to control for those possible factors that are correlated with both of our key variables. Accordingly, the empirical model takes the following general form,

$$
U_{i, t}=\alpha+\gamma S_{i, t}+\mathbf{X}_{i, t}^{\prime} \boldsymbol{\beta}+\varepsilon_{i, t}
$$

where denotes unemployment rate in region $i$ at year $t$, and denotes human capital as measured by the share of college-graduates. The coefficient of is $\gamma$. is the matrix of control variables, $\boldsymbol{\beta}$ is the corresponding vector of coefficients and finally is the error term. Control variables are chosen according to data availability therefore they do not cover every potential confounding factors. We return to this point later.

To control for other sources of increasing returns in urbanized regions we follow Ciccone and Hall (1996) and include employment density into the model. To filter the effects of labor market disadvantages arising from the remoteness and higher commuting costs of rural areas we use the regional share of population living in small settlements below the population of 1000 . We also consider it important to add control variables for the demographic structure of regions. According to Shimer (2001) higher occupational mobility of younger workers results in more elastic labor markets, lowers the costs of matching and encourages firms to open new vacancies. Therefore in regions with a higher share of population below 25 years unemployment is expected to be lower.

The variables that account for the industrial structure of region are the share of agricultural employment, the share of employment in manufacturing and construction and the Herfindahl-Hirschmann index of industrial diversity. A common argument in explaining regional unemployment disparities is that regions specialized in declining industries are expected to have higher unemployment rates while those specialized in thriving industries have lower unemployment rates. In Hungary agriculture, mining and some industries within manufacturing (e.g. manufacture of raw materials) are usually considered as declining industries, while the service sector is commonly considered as a growing sector. However, the higher share of services does not necessarily imply lower rates of unemployment. The reason is that although traditional sectors experienced a remarkable decline during the nineties the employment growth of the service sector was insufficient to offset the job-loss in declining industries. Therefore, despite of the higher employment share of the service sector unemployment might still be high. Consequently, the sign of the employment shares is ambiguous, and likely to vary by context (Elhorst, 2003). The sign of the HH-index of industrial diversity is more straightforward. According to Simon (1988), industrial diversity has a negative effect on unemployment, or more precisely, on the frictional component of unemployment. Since the fluctuation of frictional unemployment is independent from industries, in regions with diversified industrial structures it is more probable that frictional layoffs of an industry are offset by the increased labor demand of another. 
Finally we also include dummy variables for six (out of seven) NUTS-2 regions, which might control for other unobserved region-specific factors. Sub-regions located in the same part of the country might share some common characteristics which might be correlated with both regional skill endowments and unemployment.

\section{Data and descriptive statistics}

The data used in the analysis comes from two sources. For the dependent variable we rely on the database of Public Employment Office which has been providing detailed spatial data on the number of unemployed since 1993. As reliable LAU-1 data on labor market participation and employment is only available from Census records the analysis is confined to census years. Although there have been three censuses since the regime change, in the absence of comparable data on unemployment for the census year of 1990 our analysis is based on the census years of 2001 and 2011. Data is aggregated and updated according to the LAU-1 classification of 2011 which consists of 175 sub-regions.

Variable definitions and some descriptive statistics (mean, standard deviation) are presented in Table 1. The standard deviation of unemployment in 2011 is higher than in 2001, which suggest a slight increase in regional unemployment differentials. Skillspecific unemployment rates more or less reflect those shown in Figure 2, namely higher educational attainments imply lower unemployment rates. Means and standard deviations do not show any remarkable changes in either category, skill-specific unemployment rates remained stable between 2001 and 2011. The share of college graduates has increased nationwide due to the expansion of tertiary education but it has not been accompanied with the reduction of spatial disparities of human capital endowments. There has been a marked tendency towards the spatial polarization of skills in the 2000s which is attributable to skill-selective migration patterns and the spatial concentration of educational institutions.

Table 1. Definitions and descriptive statistics

\begin{tabular}{|c|c|c|c|}
\hline Variables & Definition & 2001 & 2011 \\
\hline \multicolumn{4}{|l|}{ Dependent variables } \\
\hline Unemployment rate & Unemployed persons as a percentage of the labor force (15-64 years) & $\begin{array}{l}7.418 \\
(4.125)\end{array}$ & $\begin{array}{l}11,55 \\
(5,328)\end{array}$ \\
\hline \multicolumn{4}{|l|}{ by educational categories: } \\
\hline Primary education or less & $\begin{array}{l}\text { Unemployed persons with primary education as a percentage of population with primary } \\
\text { education over } 7 \text { years of age }\end{array}$ & $\begin{array}{l}6.320 \\
(4.301)\end{array}$ & $\begin{array}{c}6,209 \\
(3,993)\end{array}$ \\
\hline Lower secondary education & $\begin{array}{l}\text { Unemployed persons with lower secondary education as a percentage of as a percentage of } \\
\text { population with lower secondary education over } 7 \text { years of age }\end{array}$ & $\begin{array}{l}7.720 \\
(3.800)\end{array}$ & $\begin{array}{l}7,755 \\
(3,802)\end{array}$ \\
\hline Upper secondary education & $\begin{array}{l}\text { Unemployed persons with lower secondary education as a percentage of as a percentage of } \\
\text { population with upper secondary education over } 7 \text { years of age }\end{array}$ & $\begin{array}{l}6.287 \\
(3.140)\end{array}$ & $\begin{array}{l}6,216 \\
(2,970)\end{array}$ \\
\hline College education or more & $\begin{array}{l}\text { Unemployed persons with tertiary education as a percentage of college educated population } \\
\text { over } 7 \text { years of age }\end{array}$ & $\begin{array}{l}1.907 \\
(0.923)\end{array}$ & $\begin{array}{l}1,906 \\
(0,909)\end{array}$ \\
\hline \multicolumn{4}{|c|}{ 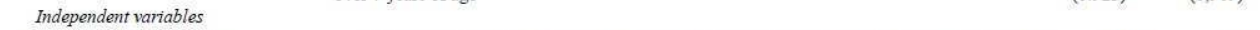 } \\
\hline Share of college graduates & $\begin{array}{l}\text { Ratio of college-educated population over } 25 \text { years of age to population over } 25 \text { years of } \\
\text { age }\end{array}$ & $\begin{array}{l}8.183 \\
(3.965)\end{array}$ & $\begin{array}{r}12,73 \\
5(5,679)\end{array}$ \\
\hline Share of young population & Percentage of population below 25 years of age & $\begin{array}{l}68.444 \\
(2.294)\end{array}$ & $\begin{array}{r}72,86 \\
4(2,753)\end{array}$ \\
\hline Employment density & Total employment in per square kilometers & $\begin{array}{r}43.123 \\
(110.867)\end{array}$ & $\begin{array}{r}46,71 \\
(117,165)\end{array}$ \\
\hline Share of rural population & Percentage of LAU-1 population living in settlements with population below 1000 & $\begin{array}{l}15.397 \\
(17.104)\end{array}$ & $\begin{array}{l}2^{15,93} \\
(17,513)\end{array}$ \\
\hline Share of employment in agriculture & Percentage of employment in agriculture & $\begin{array}{l}8.604 \\
(6.051)\end{array}$ & $\begin{array}{l}7,436 \\
(4,828)\end{array}$ \\
\hline $\begin{array}{l}\text { Share of employment in } \\
\text { manufacturing }\end{array}$ & Percentage of employment in manufacturing and construction & $\begin{array}{l}30.002 \\
(8.336)\end{array}$ & $\begin{array}{r}26,28 \\
9(8,011)\end{array}$ \\
\hline Industrial concentration $(\mathrm{HHI})$ & Herfindahl-Hirschman Index of ISIC-1 industrial employment & $\begin{array}{l}0.158 \\
(0.041)\end{array}$ & $\begin{array}{l}0,136 \\
(0,033)\end{array}$ \\
\hline Literacy rate in 1880 & Ratio of literate population to population over 7 years of age in 1880 & & 785 \\
\hline
\end{tabular}




\section{Regression results}

Table 2 reports OLS estimates for each year separately and also for the pooled crosssection of the two census years. Column 1 and 2 contains estimates for 2001. In both cases the coefficient on the share of college educated has the expected negative sign and is highly significant. The inclusion of control variables does not have any substantial impact on the key parameter. The next two columns contain estimated parameters for 2011, which yield qualitatively the same results for the share of college graduates. The inclusion of controls invariably does not make any substantial difference in the estimated parameter of human capital. Out of the six controls, three (employment density, the share of young individuals and the share of rural population) are significant in both years, while the share of employment in manufacturing is only significant in 2011 . The overall explanatory power is slightly highest in 2011. In the augmented specification the R2 exceeds 0.8 .

Table 2. The effects of the share of college-graduates on regional unemployment rates (OLS and FD results)

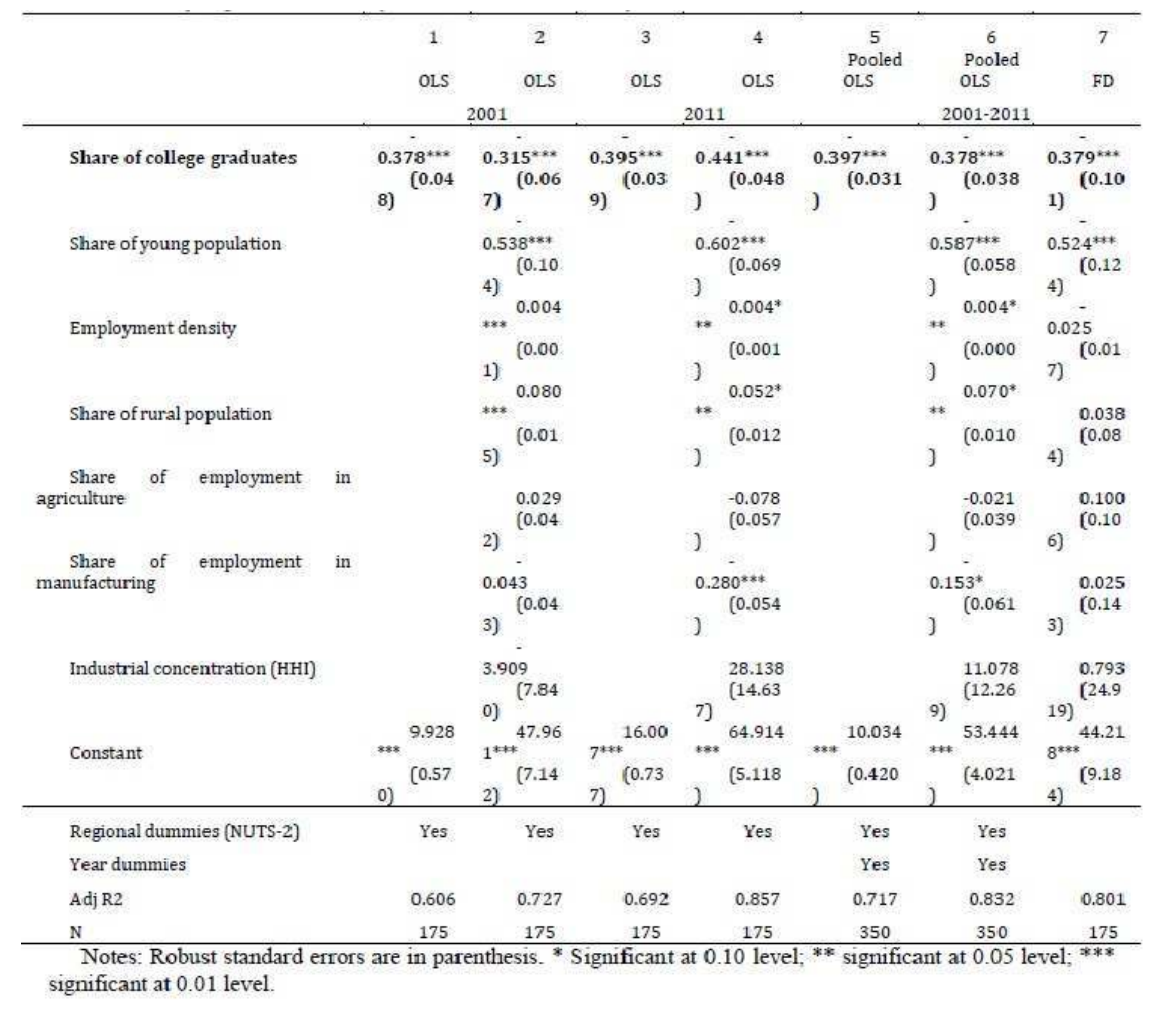

Column 5 contains the results of a pooled cross-sectional regression. With respect to the share of college graduates this result is quantitatively and substantially analogous to the previous ones. The same applies to the first differenced specification in column 6 which eliminates potential time-invariant sub-regional heterogeneity from the model. The main difference between the results of the pooled OLS and the first-differenced specifications is the changing importance of control variables. While in the pooled cross-sectional specification four out of six control variables are significant, in the first-differenced case only one control variable, the share of young individuals seems to have significant effects on unemployment. 
Although parameter estimates summarized in Table 2 suggest that the correlation between the share of college graduates and the unemployment rate is robust, OLS results might be subject to omitted variable bias. As we have mentioned before the set of control variables used in the analysis is unlikely to be exhaustive therefore it is possible that unobserved time-varying factors lead to spurious correlations. Besides, reverse causality might also be a problem; the regional unemployment rate probably exerts a causal effect on the supply of skilled workers, because limited employment opportunities incites skilled workers to move away from depressed regions with high unemployment. To overcome endogeneity bias caused by these problems we use literacy rate in 1880 as an instrument for the current share of college educated adult population and re-estimate all specifications of Table 2 using 2SLS (Two-Stage Least Squares). ${ }^{8}$ Historical variables are commonly used for identification in economic geography (Combes, Mayer \& Thisse, 2008), because the assumption on their validity is simple and highly intuitive. In the unemployment exercise it is plausible that the spatial distribution of human capital in the nineteenth century does not have any direct effects on unemployment, apart from those that prevail through the inherited spatial patterns of human capital.

Table 3. The effects of the share of college-graduates on regional unemployment rates (2SLS and FD 2SLS results)

\begin{tabular}{|c|c|c|c|c|c|c|c|}
\hline & $\begin{array}{c}1 \\
2 S L S\end{array}$ & $\begin{array}{c}2 \\
2 S L S\end{array}$ & $\begin{array}{c}3 \\
2 S L S\end{array}$ & $\begin{array}{c}4 \\
2 S L S\end{array}$ & $\begin{array}{c}5 \\
\text { Pooled } \\
\text { 2SLS }\end{array}$ & $\begin{array}{c}6 \\
\text { Pooled } \\
\text { 2SLS }\end{array}$ & FD 2SLS \\
\hline & \multicolumn{2}{|r|}{2001} & \multicolumn{2}{|c|}{2011} & \multicolumn{3}{|c|}{ 2001-2011 } \\
\hline \multicolumn{8}{|l|}{ Second Stage } \\
\hline Share of college graduates & $\begin{array}{l}-0.411^{* *} \\
(0.155)\end{array}$ & $\begin{array}{l}0.601^{2 * *} \\
(0.126)\end{array}$ & $\begin{array}{l}0.614^{* *} \\
(0.145)\end{array}$ & $\begin{array}{l}1.108^{* * *} \\
\quad(0.322)\end{array}$ & $\begin{array}{r}0.532^{* \ldots *} \\
(0.108)\end{array}$ & $\begin{array}{l}0.888^{* 4 *} \\
(0.225)\end{array}$ & $\begin{array}{l}0.658^{* *} \\
(0.224)\end{array}$ \\
\hline \multirow[t]{2}{*}{ Share of young population } & & $0.508^{* 0 *}$ & & $0.474^{* * *}$ & & $0.504^{* * *}$ & 0.043 \\
\hline & & $(0.109)$ & & $(0.117)$ & & $(0.079)$ & $(0.322)$ \\
\hline Employment density & & $0.007^{*}$ & & $0.012^{* *}$ & & $0.010^{* * z}$ & $0.173^{*}$ \\
\hline \multirow{2}{*}{$\begin{array}{l}\text { Share of employment in } \\
\text { agriculture }\end{array}$} & & $(0.003)$ & & $(0.004)$ & & $(0.003)$ & $(0.097)$ \\
\hline & & -0.065 & & $-0.461^{*}$ & & $-0.236^{*}$ & 0.084 \\
\hline \multirow{3}{*}{$\begin{array}{l}\text { Share of employment in } \\
\text { manufacturing }\end{array}$} & & $(0.111)$ & & $(0.189)$ & & $(0.101)$ & $(0.097)$ \\
\hline & & -0.077 & & $0.400^{* * *}$ & & $-0.234^{* *}$ & 0.019 \\
\hline & & $(0.067)$ & & $(0.107)$ & & $(0.085)$ & $(0.137)$ \\
\hline \multirow[t]{2}{*}{ Share of rural population } & & $0.064^{* *}$ & & -0.000 & & 0.033 & -0.167 \\
\hline & & $(0.025)$ & & $(0.030)$ & & $(0.020)$ & $(0.144)$ \\
\hline Industrial concentration $(\mathrm{HHI})$ & & -8.462 & & $\begin{array}{l}6.361 \\
(21.070\end{array}$ & & 1.127 & $\begin{array}{l}5.848 \\
(23.070\end{array}$ \\
\hline \multirow[t]{2}{*}{ Constant } & $* 10.183^{* *}$ & $\begin{array}{r}(11.486) \\
* \quad 50.977^{* *}\end{array}$ & $.18 .644^{* *}$ & ** $73.775^{*}$ & ${ }^{*} 11.112^{* *}$ & $\begin{aligned} & (17.029) \\
* & 58.197^{*}\end{aligned}$ & ${ }_{* *} 11.239^{*}$ \\
\hline & $(1.258)$ & $(7.593)$ & $(1.781)$ & $(6.697)$ & $(0.887)$ & $(4.641)$ & $(1.861)$ \\
\hline \multicolumn{8}{|l|}{ First stage } \\
\hline \multirow[t]{2}{*}{ Literacy rate in 1880} & $0.106^{* * *}$ & $0.104^{* *}$ & $0,157^{* * *}$ & $0.101^{* *}$ & $0.132^{* * *}$ & $0.062^{* * 8}$ & ${ }^{0.033^{* *}}$ \\
\hline & $(0.029)$ & $(0.020)$ & $(0.040)$ & $(0.026)$ & $(0.025)$ & $(0.016)$ & $(0.010)$ \\
\hline \multirow{2}{*}{$\begin{array}{l}\text { F-stat of excluded instrument (p- } \\
\text { value) }\end{array}$} & 13.152 & 11,83 & 15.770 & 10.061 & 28.674 & 11.224 & 8.540 \\
\hline & $(0.000)$ & $(0.029)$ & $(0.000)$ & $(0.015)$ & $(0.000)$ & $(0.000)$ & $(0.000)$ \\
\hline Regional dummies & Yes & Yes & Yes & Yes & Yes & Yes & \\
\hline Year dummies & & & & & Yes & Yes & \\
\hline Adj R2 & 0.605 & 0.699 & 0.646 & 0.698 & 0.695 & 0.748 & 0.536 \\
\hline $\mathrm{N}$ & 175 & 175 & 175 & 175 & 350 & 350 & 175 \\
\hline
\end{tabular}

2SLS results are summarized in Table 3. The lower half of the table shows the first stage estimates of instruments and the corresponding F-statistics. Although the first stage coefficients of literacy are positive and significant in each specification, the problem of weak instruments is certainly an issue in some specifications (Bound, Jaeger \& Baker 1995). In column 2 the $p$-value of the F-statistic is 0.029 which shows that literacy in 1880 has only a moderate effect on the share of college-graduates in 2001. The same applies to the specifications in column 4 in 7. In the case of column 4 the F-statistic is significant, but it hardly exceeds the critical value of 10 suggested by Stock, Wright \& Yogo, (2002). In 
column 7 where the first-difference of human capital is instrumented by literacy rates, the problem is more apparent. In this case the F-statistic is 8.5 with p-value of 0.024 .

Second stage estimates are qualitatively similar to those reported in Table 2. 2SLS provide slightly larger (in absolute values) estimates than OLS does. Parameter estimates for 2011 remain larger in each case which suggests that the effects of human capital have become larger 2001. Although the results provided by the pooled cross-sections and the firstdifferenced specification are theoretically identical to the results of the yearly crosssections, in the first-differenced specification in column 7 the estimated coefficient of the share of college-graduates is only significant at the 5 percent level. The overall explanatory power of 2SLS is lower than OLS the $\mathrm{R}^{2}$ takes values between 0.5 and 0.8 .

Table 4. Separate 2SLS estimates for skill-specific unemployment rates

\begin{tabular}{lccc}
\hline Dependent variable & 2 SLS & 2 SLS & FD 2SLS \\
& 2001 & 2011 & $2001-2011$ \\
\hline Primary education or less & $-0.385^{* * *}$ & $-0.425^{* * *}$ & $-0.489^{* * *}$ \\
& $(0.141)$ & $(0.141)$ & $(0.178)$ \\
Lower secondary education & $-0.368^{* * *}$ & $-0.289^{* * *}$ & $-0.293^{*}$ \\
Upper secondary education & $(0.103)$ & $(0.071)$ & $(0.171)$ \\
& $-0.125^{* *}$ & $-0.203^{* * *}$ & $-0.297^{* *}$ \\
College education or more & $(0.048)$ & $(0.067)$ & $(0.117)$ \\
& -0.003 & -0.009 & -0.005 \\
\hline
\end{tabular}

Notes: The share of college educated population is instrumented by 1880 literacy rate. Every specification contains a set of regional controls and the specifications for 2001 and 2011 also contain NUTS-2 dummies Robust standard errors are in parenthesis. * Significant at 0.10 level; ** significant at 0.05 level; *** significant at 0.01 level.

Although OLS and 2SLS results equally support the presumption that regional skill distribution has negative effects on unemployment rate differentials, we still do not know whether the effect is simply due to the higher demand for skilled workers, or the complementarity between skill levels. In order to assess the role of complementarity we re-estimated the augmented models on skill-specific unemployment rates. To filter out the effects of local skill compositions an alternative definition on skill-specific unemployment rates is employed. Skill-specific unemployment rates are defined as the ratios of unemployed persons with specified skill levels to the population with the same skill levels over 7 years of age.

Parameter estimates for all the four skill categories are summarized in Table 4. 2SLS estimates show that the regional share of college-educated adults has a significant negative effect on the unemployment rate of lower skilled persons. The magnitude of the effect is the largest for the primary educated group, and then the effect decreases as the educational level grows. For the highest skill category (college or more) we do not find any significant effects. The reason is probably that, skilled workers cannot necessarily compete for jobs requiring lower qualifications and displace lower-skilled workers when skill levels are imperfect substitutes. Therefore, whenever the supply of skilled workers grows beyond the region's needs, high-skilled unemployment starts to increase by the simple mechanism of supply and demand. ${ }^{9}$

On the whole, separate estimates for skill-specific unemployment suggest that the relative supply of college-educated adults is negatively associated with the unemployment rates of less educated workers, and not just between the top educational categories, but also between the extreme ends of the skill distribution. 


\section{Summary}

In this paper we explained the persistency of regional unemployment disparities on the conceptual basis of skill-biased technological change and new economic geography. We argue that if technology and skills are close complements and workers with different skills are poor substitutes, the uneven spatial distribution of human capital plays an important role in shaping regional unemployment rate differentials. Since the adaption and application of improved technologies need skilled workers, the inflow of technology raises local skill premium and attract highly qualified workers. The increasing supply of skilled labor raises local demand for unskilled labor because skilled and unskilled workers are not perfect substitutes in the production process of the traded sector, and also because the higher share of skilled workers increase the demand for the services of the local non-traded sector which employs relatively more unskilled workers. The rising share of highly qualified labor in turn reduces low-skilled unemployment.

In order to provide some empirical support for this argument we first provided an integrated overview about the major processes of the Hungarian post-socialist transition, and then conducted a formal econometric analysis on the importance of human capital on unemployment. Indirect evidences provided by the literature suggest that the spatial distribution of human capital inherited from the socialist regime had a significant role in the emergence of regional unemployment disparities. Earlier empirical studies demonstrate that the emergence of unemployment after the regime change affected mostly those regions that were endowed with lower stocks of human capital, because foreign investors (the carriers of improved technologies) rather preferred human capital rich regions.

As it is shown by our empirical results, the effects of regional human capital were intensified after the transitional process, stabilizing the spatial patterns of unemployment. Our regression estimates purport that human capital is negatively associated with regional unemployment. Separate estimates for skill-specific unemployment rates support the hypothesis of complementarity between skill levels, which means that larger shares of skilled labor reduce the unemployment rate of less skilled workers.

Although our results confirm the relevance of the Objective 3 of EU Cohesion Policy which aims to support the development of education and training, in our view education on its own is incapable of amending the disadvantageous labor market situation of peripheral underdeveloped regions. Retention of skilled labor should also be more emphasized, because the improvement of education and training do not necessarily exert its effects locally as a result of higher migration propensity of the skilled labor. Efforts on keeping these workers at place are required because their shortage might constitute a long-term constraint on potential growth. 


\section{BIBLIOGRAPHY}

Ábrahám, Á., \& Kertesi, G. (1998). Regional unemployment rate differentials in Hungary 1990-1995. The changing role of human capital. In L. Halpern \& C. Wyplosz (Eds.), Hungary Towards a Market Economy (pp. 351-377). Cambridge: Cambridge University Press.

Acemoglu, D. (1996). A micro-foundation for social increasing returns in human capital accumulation. Quarterly Journal of Economics, 111(3), 779-804.

Acemoglu, D. (2003). Patterns of skill premia. Review of Economic Studies, 70(2), 199-230.

Aghion, P., \& Blanchard, O. (1994). On the speed of transition in central Europe. NBER

Macroeconomics Annual, 9(1), 283-320.

Autor, D. H., Katz, L. F., \& Krueger, A. B. (1998). Computing inequality: Have computers changed the labor market? Quarterly Journal of Economics, 113(4), 1169-1213.

Azariadis, C., Drazen, A. (1990). Threshold externalities in economic development. Quarterly Journal of Economics, 105(2), 501-526. doi: 10.2307/2937797

Bacolod, M., Blum, S. \& Strange, W. (2009). Skills and the city. Journal of Urban Economics 65 (2), 136-153. doi:10.1016/j.jue.2008.09.003

Berg, I. (1970). Education and Jobs: The Great Training Robbery, New York, NY: Praeger.

Blanchard, O. (2006). European unemployment: the evolution of facts and ideas, Economic Policy, 21(45), 5-59.

Blanchard, O. J., \& Katz, L. F. (1992). Regional evolutions. Brookings Papers on Economic Activity, 1, 175.

Boeri, T. (2000). Structural Change, Welfare Systems, and Labour Reallocation. Lessons from the Transition of Formerly Planned Economies. Oxford MA: Oxford University Press.

Boeri, T., \& Terrell, K. (2002). Institutional determinants of labour reallocation in transition. Journal of Economic Perspectives, 16(1), 51-76.

Borjas, G. J., Bronars, S. G., Trejo, S. J. (1992). Self-selection and internal migration in the United States. Journal of Urban Economics, 32(2), 159-185. doi:10.1016/0094-1190(92)90003-4

Bornhorst, F., \& Commander, S. (2004). Regional unemployment and its persistence in transition countries. (IZA Discussion Paper 1074). Bonn, MA: Institute for the Study of Labor.

Bound, J., Jaeger, D. A., \& Baker, R. M. (1995). Problems With instrumental variables estimation when the correlation between the instruments and the endogenous explanatory variable is weak. Journal of the American Statistical Association, 90(430), 443-450.

Burridge, P., \& Gordon, I. (1981). Unemployment in the British metropolitan labour areas. Oxford Economic Papers, 33(2), 274-297.

Ciccone, A., \& Hall, R. (1996). Productivity and the density of economic activity. American Economic Review, 86(1), 54-70.

Combes, P. P., Mayer, T., \& Thisse, J. F. (2008). Economic Geography. Princeton, NJ: Princeton University Press 
Commander, S., \& Köllö, J. (2008). The changing demand for skills Evidence from the transition. Economics of Transition, 16(2), 199-221. Doi: 10.1111/j.1468-0351.2008.00303.x.

Elhorst, J. P. (2003). The mystery of regional unemployment differentials: Theoretical and empirical explanations. Journal of Economic Surveys, 17(5), 709-748.

Epifani, P., \& G. A. Garcia, (2005). Trade, migration and regional unemployment. Regional Science and Urban Economics, 35(6), 625-644. doi:10.1016/j.regsciurbeco.2004.09.003

Fazekas, K. (2005). Effects of FDI Inflows on Regional Labour Market Differences in Hungary. Économie Internationale, 102(2), 83-105.

Ferge, Zs. (1988). Teljes foglalkoztatás - foglalkoztatáspolitika - munkanélküliség. [Full Employment - Employment Policy - Unemployment]. VaIóság, 31(6), 19-31.

Ferragina, A. M., \& Pastore, F (2008). Mind the gap: Unemployment in the new EU regions. Journal of Economic Surveys, 22(1), 73-113.

Fujita, M., Krugman, P. R., \& Venables, A. J. (1999). The Spatial Economy: Cities, Regions, and International Trade, Cambridge, MA: MIT Press.

Glaeser, E. L. (1999). Learning in cities. (NBER Working Papers 6271). Cambridge, MA: National Bureau of Economic Research. doi: 10.3386/w6271

Glaeser, E. L. (2005). Smart Growth: Education, Skilled Workers and the Future of Cold-Weather Cities. Cambridge, MA: Harvard University.

Glaeser, E. L., \& Resseger, M. (2010). The complementarity between skills and cities. Journal of Regional Science, 50(1), 221-244. doi: 10.1111/j.1467-9787.2009.00635.x

Glaeser, E. L., \& Saiz, A. (2004). The Rise of the Skilled City. Brookings-Wharton Papers on Urban Affairs 5(1), 47-94. doi: 10.3386/w10191

Goos, M., Manning A., \& Salomons, A. (2014). Explaining job polarization: Routine-biased technological change and offshoring, American Economic Review, 104(8), 2509-2526. doi: 10.1257/ aer.104.8.2509

Hamermesh, D.S. (1993). Labour demand. Princeton, NJ: Princeton University Press.

Jurajda, S., \& Terrell, K. (2009). Regional unemployment and human capital in transition economies. Economics of Transition, 17(2), 241-274.

Katz, L. F., \& Murphy, K. M. (1992). Changes in relative wages, 1963-1987: Supply and demand factors. Quarterly Journal of Economics, 107(1), 35-78.

Kézdi, G. (2002). Two phases of labor market transition in Hungary: Inter-sectoral reallocation and skill-biased technological change (Budapest Working Papers 0203). Budapest, MA: IE-CERS, Hungarian Academy of Sciences.

Köllö, J. (2006). Transport costs, availability and local unemployment in Hungary. (Budapest Working Papers 0601). Budapest, IE-CERS Hungarian Academy of Sciences.

Kornai, J. (1992). The Socialist System. The Political Economy of Communism. Oxford, MA: Oxford University Press.

Lopez-Bazo, E., del Barrio, T., \& Artis, M. (2002). The regional distribution of Spanish unemployment: A spatial analysis. Papers in Regional Science, 81(3), 365-389.

Lucas, R. J. (1988). On the mechanics of economic development. Journal of Monetary Economics 22 (1), 3-42. 
Malizia, E., \& Ke, S. (1993). The influence of economic diversity on unemployment and stability. Journal of Regional Science, 33(2), 221-235.

Manning, A. (2004). We can work it out: the impact of technological change on the demand for low-skilled workers, Scottish Journal of Political Economy, 51(5), 581-608. doi: 10.1111/ j.0036-9292.2004.00322.x.

Marston, S. T. (1985). Two views of the geographic distribution of unemployment. Quarterly Journal of Economics, 100(1), 57-79.

Meusburger, P. (2001). Spatial and social disparities of employment and income in Hungary in the 1990s. In P. Meusburger, \& H. Jöns (Eds.), Transformations in Hungary Essays in Economy and Society (pp. 173-206). Berlin: Springer-Verlag.

Newell, A. (2005). Skill mismatch and regional unemployment in Poland. In F.E. Caroleo \& S. Destefanis (Eds.), Regions, Europe and the Labour Market. Recent Problems and Developments. (pp. 187202). Heidelberg: Physica-Verlag.

OECD (2005). Employment Outlook. Paris, OECD.

Overman, H. G., \& Puga, D. (2002). Regional unemployment clusters. Economic Policy, 17(34), 115148.

Partridge, M. D., \& Rickman, D. S. (1997). The dispersion in US State unemployment rates: The role of market and non-market equilibrium factors. Regional Studies, 31(6), 593-606.

Pissarides, C. A., \& Wadsworth, J. (1989). Unemployment and the inter-regional mobility of labour, Economic Journal, 99(397), 739-755.

Rauch, J. E. (1993). Productivity gains from geographic concentration of human capital: Evidence from the cities, Journal of Urban Economics, 34(3), 380-400. doi: 10.1006/juec.1993.1042

Shapiro, J. M. (2006). Smart cities: Quality of life, productivity, and the growth effects of human capital. Review of Economics and Statistics, 88(2), pp. 324-335. doi: 10.1162/rest.88.2.324

Shimer, R. (2001). The impact of young workers on the aggregate labor market. Quarterly Journal of Economics, 116(3), 969-1007. doi: 10.1162/00335530152466287.

Simon, C. J. (1988). Frictional unemployment and the role of industrial diversity. Quartely Journal of Economics, 103(4): 715-728. doi: 10.2307/1886071.

Stock, J. H., Wright, J. H., \& Yogo, M. (2002). A Survey of weak instruments and weak identification in generalized method of moments. Journal of Business and Economic Statistics, 20(4), 518-529. doi: 10.1198/073500102288618658.

Storper, M., \& Venables, A. J. (2004). Buzz: face-to-face contact and the urban economy. Journal of Economic Geography, 4(4), 351-370. doi: 10.1093/jnlecg/lbh027

Taylor, J. (1996). Regional problems and policies: A European perspective. Australasian Journal of Regional Studies, 2(2), 103-131.

\section{NOTES}

1. About the theories of job competition and screening see Berg (1970).

2. Acemoglu (1996) shows that firm investment decisions, costly matching and asymmetric information about the true skills of the future employees also make for subsequent pecuniary human capital externalities. 
3. By reviewing a bulk of microeconomic empirical studies, Hamermesh (1993) concludes that, the hypothesis of the complementarity between capital and skills might be valid.

4. The outsourcing of labor-intensive activities lead to within-industry job polarization, however at the regional level it does not necessarily develop due to the changes in the relative importance of distinct sectors and industries.

5. In this respect post-socialist transitional countries can also be seen as unique sources of natural experiments (Ferragina \& Pastore, 2008).

6. The 1949 Census was the last one to collect data on unemployment, but the results were not published until the late sixties, when they were labelled as obsolete.

7. Throughout this paper we prefer a four-category classification: (i) primary education or less, (ii) vocational and technical school, (iii) secondary schools with final examination, (iv) and college degree or more. In terms of the OECD classification, category (i) corresponds to primary education or less (ISCED 0 and 1), category (ii) roughly covers lower secondary education (ISCED 2), category (iii) refers to upper secondary education (ISCED 3) and finally category (iv) covers tertiary education or more (ISCED 5 and 6).

8. Data on literacy rates stem from the 1880 census records.

9. Another explanation was proposed by Jurajda \& Terrell (2009) who used skill-specific demographics-adjusted unemployment probabilities as independent variables. They explained the lack of significant relationship between the share of college-graduates and high-skilled unemployment probabilities with the simple fact that their independent variable had a mean close to zero and low spatial variability. This explanation, however, does not apply in our case. As it is shown by Table 1 the mean and standard deviation of our measure are about 1.9 and 0.9 for both years.

\section{ABSTRACTS}

In this paper we address the empirical question whether the skill distribution of regions has a permanent effect on regional unemployment rates. We argue that if technology and skill are complements and workers with different skills are poor substitutes, the uneven spatial distribution of human capital plays an important role in shaping regional unemployment rate differentials. When the adaption and application of technology need skilled workers, the inflow of technology raises the skill premium and attract skilled workers, which in turn also ameliorate low-skilled unemployment, if skilled and unskilled workers are not perfect substitutes in the production process, or the higher share of skilled workers in the traded sector increase the demand for unskilled labor in the local non-traded sector. Empirical evidence from the Hungarian post-socialist transition confirms the hypothesis that the uneven distribution of skills inherited from the socialist era had a major and permanent influence on the emergence of regional unemployment disparities, which prevailed even after the end of transition through the inward flow of technology through FDI and the spatial concentration of economic activity. Regression estimates show that the share of college educated individuals has a strong negative effect on regional unemployment. However this is not only the result of the initially lower risk of unemployment among college educated individuals but also the complementarity between different skill levels. Separate estimates on skill-specific unemployment rates show that an increase in the percentage share of college graduates abates the unemployment rate of lower skilled workers. 
O presente artigo se pergunta se a distribuição regional de qualificações profissionais tem efeito permanente sobre as taxas regionais de desemprego. Argumentamos que se tecnologias e qualificações são complementos e se trabalhadores com diferentes habilidades são substitutos mais frágeis, a desigual distribuição espacial do capital humano joga papel de relevo na conformação das taxas diferenciais regionais de desemprego. Quando a adaptação e a aplicação de tecnologia precisa de trabalhadores qualificados, o influxo de tecnologia incrementa as remunerações e os atrai, além de também melhorar as taxas de desemprego de baixa qualificação - se trabalhadores qualificados e não-qualificados não são perfect substitutes no processo produtivo ou se a maior parte de trabalhadores qualificados no comércio incrementa a demanda por trabalho não-qualificado no setor local de bens não-transacionáveis. Evidências empíricas oriundas da transição pós-socialista vivida pela Hungria confirmam a hipótese segundo a qual a distribuição desigual de qualificações herdade da era socialista teve influência importante e permanente sobre a emergência de disparidades regionais de desemprego - as quais prevaleceram mesmo após o fim da transição através do fluxo de tecnologia por meio do investimento estrangeiro direto e da concentração espacial da atividade econômica. Estimativas de regressão mostram que a porção de indivíduos com ensino superior exerce forte efeito negativo sobre o desemprego regional. Entretanto, isto não é apenas resultado do inicialmente menor risco de desemprego entre aqueles indivíduos, mas, também, da complementariedade entre diferentes níveis de qualificação. Estimativas próprias sobre taxas de desemprego referentes a qualificações específicas mostram que um aumento na percentagem de possuidores de diplomas de nível superior diminui a taxa de desemprego dos trabalhadores com qualificação mais baixa.

Cet article s'interroge si la distribution régionale des qualifications professionnelles joue un effet permanent sur les taux du chômage régionaux. On comprend que si les technologies et les qualifications sont complémentaires et si les ouvriers avec différentes qualifications sont des piètres substituts, la distribution inégale du capital humain joue un rôle importante sur les taux différentielles du chômage régionaux. Quand l'adaptation et l'application de technologie a besoin des ouvriers qualifiés, l'influx de technologie augmente les salaires et les attire, ainsi qu'accroit les taux de chômage des ouvriers moins qualifiés - si les ouvriers qualifiés et non-qualifiés ne sont pas des substituts parfaits dans le processus productif ou si la plus grande partie des ouvriers qualifiés dans le commerce dynamise la demande par des ouvries non-qualifiés dans le secteur local de biens non-échangables. Les évidences empiriques liées à la transition vers le capitalisme confirment l'hypothèse selon laquelle la distribution inégale des qualifications heritiées de l'époque socialiste a eu une influence si relevante que permanente sur l'émérgence des disparités du chômage régionaux. Ces disparités sont restées même après la fin de la transition et avec le flux technologique des investissements étrangères et la concentration spatiale de l'activité économique. Les estimations de régression montrent que la proportion de personnes ayant fait des études supérieures a un effet fortement négatif sur le chômage régional. Cependant, cela n'est pas seulement le résultat du risque de chômage initialement plus faible parmi ces personnes, mais également de la complémentarité entre les différents niveaux de qualification. Les propres estimations du taux de chômage pour certaines qualifications montrent qu'une augmentation du pourcentage de titulaires de diplômes de niveau supérieur réduit le taux de chômage des travailleurs peu qualifiés.

El presente artículo se pregunta si la distribución regional de cualificaciones profesionales tiene un efecto permanente sobre las tasas regionales de desempleo. Argumentamos que si las tecnologías y las calificaciones son complementos y si los trabajadores con diferentes habilidades son sustitutos más frágiles, la desigual distribución espacial del capital humano juega un papel importante en la conformación de las tasas diferenciales regionales de desempleo. Cuando la 
adaptación y la aplicación de la tecnología necesitan trabajadores calificados, el influjo de la tecnología incrementa las remuneraciones y los atrae, además de también mejorar las tasas de desempleo de baja calificación - si los trabajadores cualificados y no calificados no son sustitutos perfectos en el proceso productivo o si la mayoría de los trabajadores calificados en el comercio incrementa la demanda de trabajo no calificado en el sector local de bienes no transables. Evidencias empíricas derivadas de la transición post-socialista vivida por Hungría confirman la hipótesis según la cual la distribución desigual de cualificaciones de la era socialista tuvo una influencia importante y permanente sobre la emergencia de disparidades regionales de desempleo - las cuales prevalecieron incluso después del final de la transición a través del flujo de tecnología a través de la inversión extranjera directa y de la concentración espacial de la actividad económica. Las estimaciones de regresión muestran que la porción de las personas con educación superior ejerce un fuerte efecto negativo sobre el desempleo regional. Sin embargo, esto no es sólo el resultado del inicialmente menor riesgo de desempleo entre aquellos individuos, sino también de la complementariedad entre diferentes niveles de calificación. Las estimaciones propias de las tasas de desempleo relativas a las cualificaciones específicas muestran que un aumento en el porcentaje de poseedores de títulos de nivel superior disminuye la tasa de desempleo de los trabajadores con una calificación más baja.

\section{INDEX}

Palabras claves: distribución de cualificaciones, desempleo, disparidades regionales, transición económica, Hungría

Mots-clés: répartition des qualifications, chômage, disparités régionales, transition économique, Hongrie

Palavras-chave: distribuição de qualificações, desemprego, disparidades regionais, transição econômica, Hungria

Keywords: skill distribution, unemployment, regional disparities, economic transition, Hungary

\section{AUTHORS}

\section{LÁSZLÓ CZALLER}

Hungarian Academy of Sciences (MTA), Institute of Economics. Email: czaller@gmail.com

\section{HAJNALKA LŐCSEI}

Eötvös Loránd University (ELTE), Department of Regional Science. Email:

locsei.hajnalka@gmail.com 